\title{
PENYULUHAN PEMANFAATAN AIR HUJAN KELURAHAN JAGABAYA III KECAMATAN WAY HALIM KOTA BANDAR LAMPUNG
}

\author{
Yuda Romdania*, Ahmad Herison, Ofik Taufik Purwadi, \\ Endro Prasetyo Wahono, Sumiharni
}

Jurusan Teknik Sipil Universitas Lampung, Bandar Lampung

Jl. Prof. Sumantri Brojonegoro No.1 Bandar Lampung 35145

Penulis Korespodensi : yudaromdania@yahoo.com 1

\begin{abstract}
Abstrak
Kelurahan Jagabaya III merupakan salah satu kelurahan yang padat penduduknya. Dengan kondisi penampang saluran yang belum sesuai maka diperlukan usaha preventif untuk menghindari luapan air dari drainase yang dapat menimbulkan genangan/banjir. Tujuan dari kefgiatan ini adalah pemanfaatan air hujan demi menghindari kerusakan lingkungan baik dari meluapnya drainase,banjir, dan sebagainya, serta memberikan pengetahuan kepada masyarakat mengenai pentingnya pemanfaatan air hujan dan bagaimana cara menerapkannya dalam kehidupan sehari- hari dalam bentuk kegiatan penyuluhan. Lokasi Penyuluhan Pemanfaatan Air Hujan berlokasi di Balai Kelurahan Jagabaya III, Kecamatan Way Halim. Metode pelaksanaan kegiatan meliputi pengambilan data primer, pengolahan data dengan menggunkaan data curah hujan, dan penyuluhan. Kegiatan penyuluhan tersebut diikuti oleh Pemerintah Setempat dalam hal ini Pegawai serta Lurah Jagabaya III, dan masyarakat sekitar. Pengolahan data dengan memperhitungkan curah hujan harian rerata, koefisien tampungan hujan melalui atap dan menganalisa keksesuaian tampungan dengan curah hujan yang ada. Solusi pemanfaatan air hujan yang sesuai untuk Kelurahan Jagabaya III adalah sistem jaringan air hujan yang ditampung dalam tangki air melalui proses filtrasi kemudian diteruskan ke sumur resapan dan kelebihan air yang tidak terserap akan disalurkan ke dalam saluran pembuangan.
\end{abstract}

Kata kunci: Pemanfaatan Air Hujan, Sumur Resapan, Banjir, Jagabaya III

\section{Pendahuluan}

Air merupakan elemen yang penting dalam kehidupan manusia. Kebutuhan akan air menjadi salah satu yang penting dalam proses kehidupan. Menurut temuan terbaru WHO, lebih dari 1,1 milyar orang pada wilayah pedesaan dan perkotaan kini kekurangan akses terhadap air minum dari sumber yang berkembang dan 2,6 milyar orang tidak memiliki akses terhadap sanitasi dasar. Dampak kesehatan dari tidak terpenuhinya kebutuhan dasar terhadap air bersih dan sanitasi diantaranya rentan terhadap anak-anak. Hal ini sangat memperihatinkan, dan salah satu cara mengatasinya adalah memberikan akses yang lebih besar terhadap penyediaan air di berbagai wilayah di Indonesia (Kementerian Kesehatan RI, 2007).

Salah satu sumber air yang sering luput dari perhatian kita adalah air hujan. Air hujan yang jatuh kepermukaan bumi terkadang tidak dikelola dengan baik. Padahal jika dikelola dengan baik, air hujan dapat menjadi sumber yang bermanfaat bagi masyarakat, khususnya yang kesulitan terhadap akses air bersih. Air hujan tersebut dapat membantuk kegiatan masyarakat seperti memasak, mencuci, mandi, bahkan untuk air minum. Masyarakat belum sepenuhnya menyadari betapa pentingnya air hujan dalam kehidupan. Selama ini masih banyak anggapan bahwah ujan hanyalah suatu peristiwa alam yang terlewat begitu saja, sehingga pengelolaan yang buruk ini dapat menimbulkan permasalahan lingkungan seperti banjir.

Pentingnya sanitasi dan air bersih seyogyanya diutamakan dalam kehidupan seharihari. Dari uraian data diatas, dapat dilihat pentingnya kedua aspek tersebut dan perlu ada usaha memperbaiki dalam rangka pemenuhan kebutuhan dasar terhadap air bersih dan peran serta dalam melestarikan lingkungan. Kegiatan ini merupakan suatu bentuk penyediaan alat dimana dapat berguna untuk menyediakan air bersih melalui proses penyaringan sederhana, yaitu 
dengan membuat sumber air bersih alternatif dengan memanfaatkan air hujan.

Alokasi anggaran air bersih dan sanitasi belum cukup untuk memenuhi kebutuhan air yang ideal. Dari kebutuhan anggaran Rp. 36,1 triliun, pemerintah hanya mengalokasikan sebanyak $10 \%$ untuk pemenuhan kebutuhan air bersih masyarakat. Padahal setidaknya pemerintah dapat memenuhi 30\% dari kebutuhan itu (Tempo,2008). Ini menjadi salah satu penyebab kurang meratanya ketersediaan air bersih di seluruh wilayah di Indonesia khususnya daerah pedesaan. Minimnya aloksi dana yang disediakan menyebabkan ketidakmampuan dalam menutupi kebutuhan ketersediaan air bersih, sehingga menimbulkan masalah di berbagai daerah. Banjir dan kekeringan sekarang ini sudah menjadi permasalahan yang mendasar, khususnya di berbagai wilayah di Indonesia. Peristiwa alam ini memicu terjadinya kekurangan air bersih di beberapa wilayah. Hal ini kurang lebih juga terjadi karena adanya pengelolaan lingkungan yang kurang baik. Faktor yang ingin ditekan kan saat ini adalah faktor pengelolaan air hujan yang kurang memadai. Air hujan merupakan sumber air yang banyak tersedia di alam dan dapat diakses secara gratis. Pengelolaan yang baik dari air hujan tidak hanya akan megatasi permasalahan ketersediaan air di musim kemarau dan kelebihan air di musim hujan, tetapi juga akan meminimalisasi penggunaan dana. Langkah awal untuk memanfaatkan atau mengolah air hujan rumah tangga adalah dengan cara mengetahui kapasitas tampungan dan juga jumlah curah hujan yang ada, untuk itu diperlukan pengukuran curah hujan yang melewati atap rumah.

Kelurahan Jagabaya III merupakan salah satu daerah di Kota Bandar Lampung yang sangat padat, yaitu terdiri dari pemukiman masyarakat, perkantoran dan rumah sakit. Oleh karenanya banyak terdapat kegiatan yang memerlukan pemanfaatan air hujan demi menghindari kerusakan lingkungan baik dari meluapnya drainase,banjir, dan sebagainya. Serta memberikan pengetahuan kepada masyarakat mengenai pentingnya pemanfaatan air hujan dan bagaimana cara menerapkannya dalam kehidupan sehari- hari dalam bentuk kegiatan penyuluhan.

\section{Analisis Situasi dan Permasalahan}

\section{A. Analisis Situasi}

Adapun batas-batas wilayahKelurahan JagabayaIII adalah sebagaiberikut Sebelah Utara berbatasan dengan Kelurahan Gunung Sulah danKelurahan Way Halim Permai Kecamatan Way Halim, Sebelah Timur berbatasan dengan Kelurahan Kali Balau KencanaKecamatan Kedamaian, Sebelah Selatan berbatasan dengan Kelurahan Tanjung Baru danKelurahan Jagabaya II Kecamatan Way Halim, Sebelah Barat berbatasan dengan Kelurahan Jagabaya II Kecamatan WayHalim.

Kelurahan Jagabaya III merupakan salah satu kelurahan yang padat penduduknya, jenis bangunan di kelurahan ini juga beragam, mulai dari perumahan, pertokoan, rumah makan, fasilitas olahraga, kantor, hotel, dan lain- lain. Untuk kajian ini dikhususkan untuk pemanfaatan air hujan untuk rumah tinggal, dikarenakan pentingnya pemanfaatan air hujan melaui kesadara masyarakat untuk berperan aktif sebagai langkah antisipasi banjir.

\section{B. Perumusan Masalah}

Sebagai salah satu cata preventif terhadap banjir adalah dengan cara meningkatkan kesadaran masyarakat, salah satunya adalah edukasi mengenai pemanfaatan air hujan. Intensitas hujan yang terjadi di kawasan Jagabaya III cukup tinggi dilihat dari kondisi kepadatan pemukiman dan bangunan yang ada sehingga kurangnya daerah resapan air dan sering terjadi luapan sungai dan tidak berfungsi dengan baik drainase yang ada serta dimensi penampang salurannya yang belum sesuai, kondisi saluran drainase di Kelurahan Jagabaya III dapat ditunjukkan pada gambar dibawah ini.

Dengan kondisi penampang saluran yang belum sesuai maka diperlukan usaha preventif untuk menghindari luapan air dari drainase yang dapat menimbulkan genangan/banjir, salah satunya adalah sistem pemanfaatan air hujan. Serta memberikan edukasi mengenai pemanfaatan air hujan kepada masyarakat untuk skala rumah tinggal sehingga dapat temanfaatkan dan direalisasikan untuk kepentingan masyarakat.

\section{Metode}

\section{A. Lokasi Kegiatan}

Lokasi Penyuluhan Pemanfaatan Air Hujan berlokasi di Balai Kelurahan Jagabaya III, Kecamatan Way Halim. 


\section{B. Alat dan Bahan}

\section{1) Alat}

Adapun alat yang digunakan dalam kegiatan ini adalah sebagai berikut:

1. Soundystem

2. Michrophone

3. Tenda

4. Kursi

2) Bahan

Adapun bahan yang digunakan dalam kegiatan ini adalah sebagai berikut:

1. Fotocopy Materi

2. Snack

\section{Metode Pelaksanaan Kegiatan}

1) Pengambilan data primer:

a. Pengukuran Luas Bangunan

b. Pengukuran Luas Atap Bangunan

2) Pengolahan data dengan memperhitungkan curah hujan harian rerata, koefisien tampungan hujan melalui atap dan menganalisa keksesuaian tampungan dengan curah hujan yang ada.

3) Penyuluhan dilakukan di kantor Kelurahan Jabagaya III

\section{Pelaksanaan Pengabdian}

A. Kegiatan Penyuluhan

Kegiatan penyuluhan tersebut diikuti oleh Pemerintah Setempat dalam hal ini Pegawai serta Lurah Jagabaya III, dan masyarakat sekitar. Kegiatan Penyuluhan ini di sampaikan oleh Tim Pengabdian Jurusan Teknik Sipil, Universitas Lampung.

Materi yang diberikan dalam kegiatan penyuluhan meliputi:

1. Penjelasan pengertian air hujan dan siklus hidrologi

2. Penjelasan pemanfaatan air hujan dalam kehidupan sehari-hari

3. Penjelasan sistem air hujan dan dampak negatif air hujan

4. Penjelasan hasil identifikasi lapangan (pendataan jenis atap di lingkungan kelurahan Jagabaya III Kecamatan Way Halim)

5. Perhitungan dan perancangan bangunan pemanenan air hujan di kelurahan Jagabaya III Kecamatan Way Halim

Penyampaian materi dilakukan dengan cara andragogi dan diskusi.

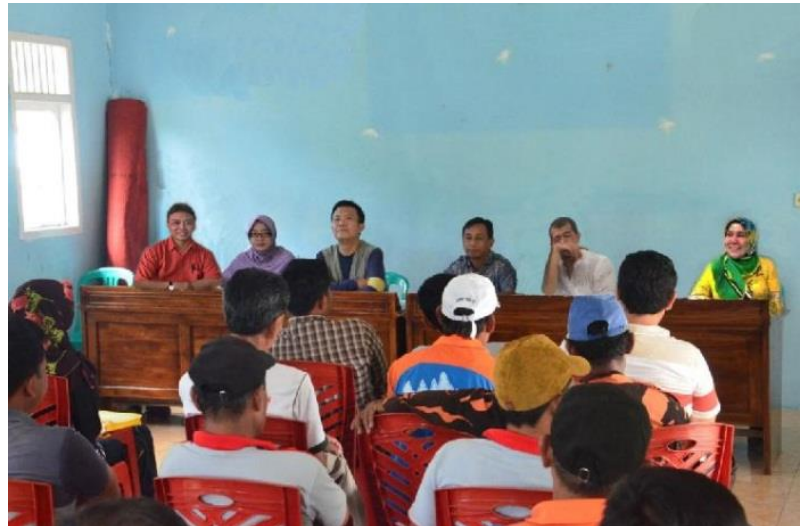

Gambar 1. Kegiatan PenyuluhandiKelurahan Jagabaya III

\section{B. Pengambilan data}

1. Pengambilan dataprimer:
a. PengukuranLuasBangunan
b. PengukuranLuas AtapBangunan

2. Pengolahan data dengan memperhitungkan curah hujan harian rerata, koefisien tampungan hujan melalui atap dan menganalisa keksesuaian tampungan dengan curah hujan yang ada.

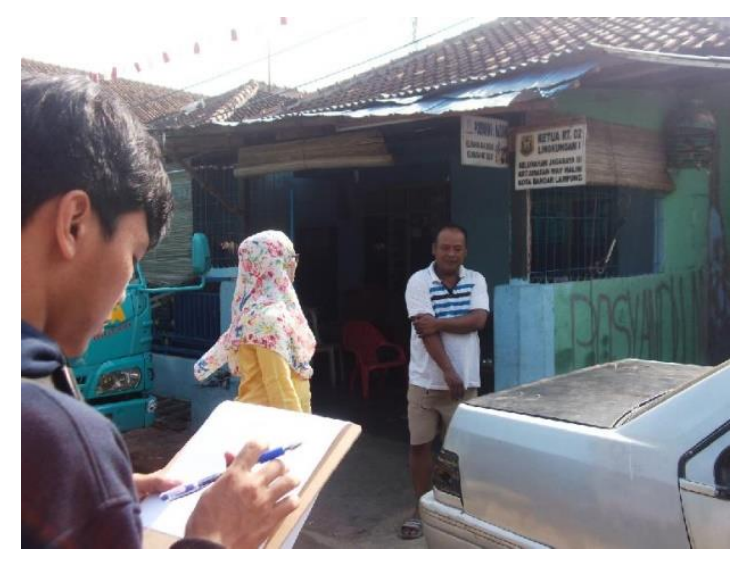

Gambar 2. Proses Pengambilan Data di Lapangan

\section{Penutup}

Dari kegiatan yang dilakukan didapatkan kesimpulan sebagai berikut:

a. Kelurahan Jagabaya III merupakan daerah yang padat penduduk, sehingga diperlukan analisa pemanfaatan air hujan untuk dapat menanggulangi salah satu permasalahan banjir di lokasi tersebut.

b. Solusi pemanfaatan air hujan yang sesuai untuk Kelurahan Jagabaya III adalah sistem jaringan air hujan yang ditampung dalam tangki air 
melalui proses filtrasi kemudian diteruskan ke sumur resapan dan kelebihan air yang tidak terserap akan disalurkan ke dalam saluran pembuangan.

c. Air hujan yang telah difiltrasi dan masuk dalam penampungan tangki air dapat dimanfaatkan warga untuk mandi, cuci dan kakus (MCK)

\section{Ucapan Terima Kasih}

Terima kasih disampaikan kepada LPPM Universitas Nasional Jakarta yang telah mendanai kegiatan Pengabdian Masyarakat ini.

\section{Daftar Pustaka}

Prabhakaran J., D., Kavitha. (2012). Ethnomedicinal importance of Mangrove species of Pitchavaram. International Journal of Research in Pharmaceutical and Biomedical Sciences. 3 (2) : 611-614.

Kementerian Kesehatan RI. 2007. Kekurangan Akses Terhadap Air Minum Dan Sanitasi Dasar 